\title{
German Research Society
}

It is appropriate that the activities of the German Research Society should be described in this issue of Europhysics News which will be distributed to delegates at the second EPS General Conference in Wiesbaden, Fed. Rep. Germany, from 3-6 October 1972. This organization is responsible for the promotion of scientific research, including physics, in the host country, and has supported the Conference by providing grants to some participants.

The German Research Society (GRS) is the central organization for the promotion of research in the Federal Republic of Germany, including West Berlin. All branches of science - the physical sciences, as well as the humanities, - pure sciences, as well, as applied sciences - are its responsibility. It is a selfgoverning body registered under private law and has the following aims:

to provide financial assistance for research projects ;

to advise the government and public authorities on scientific matters ;

to encourage close relations between scientific and industrial circles ;

to promote German co-operation in international scientific life ;

to give encouragement to young scientists.

The distribution of the GRS resources among fields of research is guided largely by the initiative of the workers themselves. The co-ordinating and planning function of the GRS is effected in different programmes. For example, there are over 80 priority programmes, Special Research Areas at the universities, programmes for the installation of computers, scientific libraries, etc. In 1970 the budget amounted to 318 million DM. 118.5 million DM were allocated to regular research projects, 64.5 million DM to the Special Research Areas, 69.1 million DM to the priority programmes, the percentage distribution within the latter being as follows :

natural sciences $49.2 \%$, engineering sciences $20.1 \%$, medical sciences $16 \%$, agricultural, veterinary and forestry sciences $4.7 \%$, and humanities $10 \%$.

\section{Principal methods of operation}

The GRS is not a government planning authority for research; its function is first to give support to projects initiated and planned by individual research workers and second to promote science with specially planned programmes: for example, the priority programmes and the programme for Special Research
Areas. The GRS plays a part in the development of official science policy by offering suggestions and advice to both the Federal and the State Governments, and by publishing surveys indicating the existing position and the development requirements in the different fields; these activities are carried out mainly by specialist scientific commissions. The GRS is, moreover, often requested to give opinions or reports on individual scientific problems or on general problems of promotion of scientific research.

In response to proposals received from research establishments, the GRS makes grants to cover equipment, personnel, travel and publication expenses for suitable selected projects which are clearly defined in subject and duration. Fellowships are awarded for research and advanced studies. Sabbatical leave for members of university staffs is supported and guest professors are financed. GRS provides financial support for German scientists to attend and participate actively in international scientific meetings abroad. The GRS also supports guest lectures of German scientists abroad. Special 'priority programmes' are drawn up to deal with specific subjects in fields particularly in need of development, and research workers may put forward their proposals for consideration under this heading. Special Research Areas are set up at universities to promote the concentration of scientific work and interdisciplinary co-operation among scientists. The GRS also makes grants for special programmes such as the development of scientific libraries, and the provision of electronic computers and of other expensive equipment.

Co-ordination of scientific effort is effected through the GRS scientific commissions by organizing symposia on specific subject to which selected specialists are invited, and by means of the 'priority programmes', and the Special Research Areas; arrangements are also made for the fellowship holders to meet and to exchange ideas.

The GRS gives its regular support not to research institutions as such,

\section{physics today}

\author{
A monthly news \\ magazine
}

Going to some 62,000 readers worldwide $-8,000$ outside the United States - PHYSICS TODAY offers an overview of contemporary physics. Recent issues focused on Electro-Optics (March), Vacuum Technology and Surface Science (August), and International Union of Pure and Applied Physics (September).

Individual Ordinary Members of the European Physical Society are cordially invited to subscribe at the special rate of $\$ 8.00$ per year. Copies are mailed air freight to Europe. Please mail your check to

\section{American Institute of Physics * \\ 335 East 45th Street New York, N.Y. 10017 U.S.A. Attn : \\ BN Department}

Please indicate EPS Membership when writing.

\footnotetext{
* Founded in 1931, the American Institute of Physics is a federation of leading societies in the field of Physics. PHYSICS TODAY goes to all members of the American Physical Society, American Assn. of Physics Teachers, Acoustical Society of America, Optical Society of America, Society of Rheology, American Crystallographic Association and American Astronomical Society.
} 
but rather to individual research workers and projects.

\section{Relations with the Government,}

The GRS is an independent selfgoverning body, responsible only to itself, and free to choose its scientific members and collaborators at will.

While the GRS receives most of its financial support from the Federal Government (via the budget of the Ministry for Education and Scientific Research) and from the State (Länder) Governments (under the Konigstein Agreement), on the whole, it is not restricted as to the disposal of these funds. However, the governments do nominate representatives to those bodies of the GRS which make financial decisions, namely the Main Committee (Hauptausschuss) and the Board of Trustees (Kuratorium); government authorities also examine the accounts.

\section{Administrative and financial structure}

The GRS has members who constitute the General Assembly (Mitgliederversammlung), which determines the broad lines of activity and elects the Executive Committee (Präsidium) and the Senate (Senat). The Executive Committee comprises President and six Vice-Presidents, who are elected for three-year terms. A delegate of the Donors' Association for the Promotion of Sciences and Arts (Stifterverband für die Deutsche Wissenschaft, a fund raising organization of industrialists, bankers, businessmen and scientists) also sits on the Executive Committee in an advisory capacity.
The Senate comprises 33 research scientists, of whom 30 are elected for three-year terms by the General Assembly, and three are ex-officio members (the Chairman of the Conference of the Academies of Sciences; the President of the Max Planck Society for the Advancement of Science ; and the President of the Rectors' Conference). The functions of the Senate are to co-ordinate the scientific activities, to give advice to the government bodies, and to look after the interests of science in international relations. Its work is supported by 27 specialist scientific commissions already mentioned.

The Board of Trustees comprises members of the Senate plus six representatives of the Federal Government, 11 representatives of the State Governments, and five representatives of the Donor' Association. This Board attends to the budget.

The Main Committee comprises 15 members of the Senate, six representatives of the State Governments, and two representatives of the Donors' Association ; its function is to decide on applications made to the Society for research grants. The Society is assisted in its work of assessing proposed projects by 28 scientific committees (Fachausschüsse), comprising altogether 385 consultants representing 148 subjets. These consultants are elected by secret ballot among all the scientists of the Fed. Rep. Germany, including West Berlin, every four years.

There are also advisory committees on library and publications matters, whose members are appointed by the Main Committee, and a Committee for
Applied Research whose members are appointed by the Senate.

A Commission for International Organizations and Projects advises the President and the boards of the Society on all international matters. At the same time, it functions as the National Committee for the Internation Council of Scientific Unions (ICSU).

The current business of the Executive Committee is carried out by a staff headed by the Secretary-General, and organized in three main sections.

\section{Officers}

Chairman of Executive Committee :

\section{J. Speer}

Secretary General : C.H. Schiel

Chairman of the Commission for International Organizations and Projects and Vice-President : H. Pick

\section{Publications}

The GRS does not publish a scientific journal itself but gives financial support to some 120 periodicals.

The GRS does not run any systematic scientific documentation service, but disseminates information on its activities to scientists and to the general public by means of bulletins, communications from the specialist scientific commissions and the surveys mentioned above.

An Annual Report is published regularly. The surveys and communications referred to above are published irregularly, as are also the research reports on the 'priority programmes'. Four time a year, information booklets (Mitteilungen) are published.

Further information is available from German Research Society, 53 BonnBad Godesberg, Kennedyalle 40.

\section{Trends in Physics}

The following Plenary Lectures are scheduled to be presented at the Second General Conference of the European Physical Society in Wiesbaden, Fed. Rep. Germany, from 3-6 October 1972, and published under the title 'Trends in Physics', expected to be 324 pp, A5.

The origin of the universe

W. Kundt (Hamburg)

Environment, scientific research and economic policy

J. Tinbergen (The Hague)

Recent developments in high energy physics

L. van Hove (Geneva)

Nonlinear optics and short light pulses W. Kaiser (Munich)

Applications of superconductivity B.B. Goodman (London)

Chemical lasers and chemical reactions
induced by lasers
A. Oraevski (Moscow)
Physics and society
H.B.G. Casimir (Eindhoven)
High temperature plasma physics and
the problem of fusion
L.A. Artsimovich (Moscow)
Physical aspects of displays
S. van Houten (Eindhoven)
Polarized neutrons and nuclei :
nuclear pseudomagnetism
A. Abragam (Paris)

Origin of biological information M. Eigen (Göttingen)

Lasers and the atmospheric sciences G. Fiocco (Frascati)

Atoms dressed by photons

C. Cohen-Tanoudji (Paris)

Exotic atoms

V. Telegdi (Chicago)

The computer and the teaching of physics

Y. Le Corre (Paris)

The volume may be ordered now for Swiss Fr. 55.- (including postage). Ind. Ord. Members of EPS. pay Swiss Fr. 50.-

Please send your order now with payment to European Physical Society, Trends in Physics, PO Box 39, CH-1213 Petit-Lancy 2, Switzerland 